\title{
Sacred Buddhistic monuments in the Himalaya: indicators and protectors from mountain hazards
}

\author{
Johannes T. Weidinger ${ }^{1,2}$ \\ 'Institute of Geology and Palaeontology, University of Salzburg, Hellbrunnerstr. 34, A-5020 Salzburg, Austria \\ ${ }^{2}$ Erkudok Institute, Kammerhofgasse 8, A-4810 Gmunden, Austria \\ (E-mail: jweidinger@hotmail.com)
}

\begin{abstract}
Sacred religious monuments such as chörten, and stone-walls (carved with religious inscriptions) can be found all along the Himalaya in and around villages dominated by Buddhist population. These structures are found to have been erected not only around monasteries and other holly places, but also in areas where mountain hazards such as torrent, debris flow and snow avalanche occur. Careful observation of the location of these structures indicate that they were erected also to serve as indicators, silent witnesses and even to protect settlements and farmland from hazards. The reason why this practice is typical for the Buddhistic-Lamaistic region of the Himalaya must partly be due to a wide prevelance of various hazardous geomorphological processes occuring within the Higher Himalaya and Trans Himalayan valleys, which forms the homelands of the Tibetan culture. The position of the sacred structures may be used as a good indicator for the past hazardous events that occured at a certain time. Some structures also seem to have been built for only a symbolic value. Thus their position can be used for finding or delimiting areas, which may fall in the "red zone" on mapping mountain hazards.
\end{abstract}

\section{INTRODUCTION}

While mapping geologic and morphologic mountain hazards, such as landslides and erosional processes in different areas of the Himalayas, the author recognized that a large number of sites of past occurrences of such processes have been marked with sacred religious structures or monuments by local people. Therefore, it is evident that these natural processes were well-recognized or eye witnessed by them hundreds or even thousands of years ago and must have occured repeatedly. As symbols of warning and for drawing attention for future generations, the prists encouraged the local inhabitants to erect these structures with the hidden message that the area lies in a hazardous zone. Today, most of the local people do not understand the purpose of erecting these structures. However, these structures could be of great use to modern day geoscientists to link between the ethno-religious components and geo-hazards.

\section{CHÖRTEN (SACRED MONUMENT) AS PROTECTORS FROM NATURAL HAZARDS}

Chörten is the most typical structure in and around the Buddhistic-Lamaistic settlement areas in the northern parts of the Himalaya in Nepal and India as well as in Tibet. They are found not only around monasteries but also along major trails, on main trail crossings or on high mountain passes. Legend has it that the dead body of Lord Buddha was divided and deposited in thousands of chörtens of all countries following his faith. That is why a chörten symbolizes the enlightened spirit of Buddha. Until recent times chörten which is one of the most important symbols of Tibetan culture has been used as a site of deposition of ashes of dead bodies and private belongings of famous lamas (lama = lamaistic priest). Their shape is a symbol of the buddhistic philosophy. Chörten are often adorned with prayer flags particularly in Nepal. Quite often it is found that given their specific positions, chörten may have been originally built to remind people of hazardous natural events or as passive symbolic or active preventors from new catastrophic events.

\section{“MANI-WALLS" AS PROTECTORS FROM MOUNTAIN HAZARDS}

"Mani-wall" is a sacred structure in Buddhist culture and are widely constructed in the Himalaya. It is made of a stone-seted core covered by flat stones carved with religious inscription "Om mani padme hum" (= religious sentence for meditation). Due to their form, shape, and position, the maniwalls in general often seem to have been erected as structures to protect the settlements or farmland from debris flows, floods and stone falls. Depending on the exponation of the area protected by them they can function in different ways:

(i) In the form of protection walls along banks of big rivers. They are erected in hundreds of places all along the Himalaya to prevent farmland or houses from floods and related mud-flows.

(ii) To protect farmland and villages from avalanches, landslides and debris flows when they are erected in very narrow river gorges. 


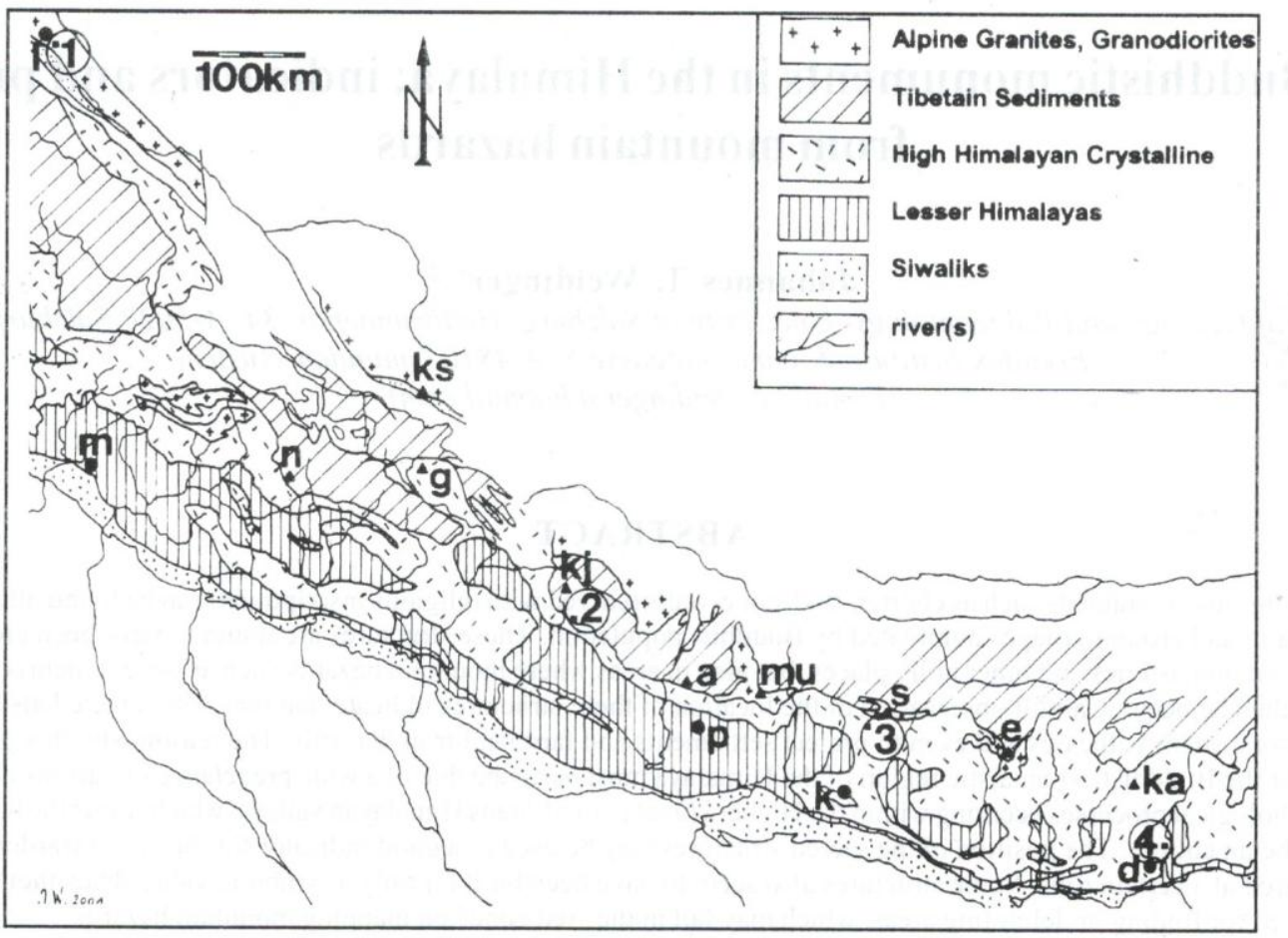

Fig. 1: Geotectonic Sketchmap of the Himalaya (compiled and simplyfied after Fuchs, 1982) with the location of the four areas with sacred buddhistic structures near hazardous mountains in Ladakh (.1), western (.2) and central Nepal (.3) and in Sikkim (.4): l-Leh, m-Mussourie, p-Pokhara, k-Kathmandu, d-Darjeeling, ks-Kailas (6,700 m), n-Nanda Devi (7,820 m), g-Gurla Mandata, kj-Kanjiroba (7,043 m), a-Annapurna (8,078 m), mu-Manaslu, s-Shisha Pangma (8,027 m), e-Mount Everest $(8,848 \mathrm{~m})$, ka-Kangchendzönga $(8,598 \mathrm{~m})$.

In the Langtang valley of Nepal, good examples of structures erected for the latter purpose mentioned above can be found (Weidinger 2001). Four examples of these special positionings of sacred structures are described in this paper (Fig. 1).

\section{THE INDUS VALLEY ALONG THE STAKMA RIVER BETWEEN SHEY AND TIKSE, LADAKH, INDIA}

The rocks of the Indus-Zangpo-Suture-Zone represent the oceanic crust that was extruded during the closure of the Neotethys around $50 \mathrm{Ma}$ ago as a result of the collision between northward moving India and the Eurasian Lhasa block. North of this area in Tibet, older clastic sediments known as Shigatse-Flysch are found. In Kohistan (Pakistan) and Ladakh (India) the deeply eroded rudiments of a magmatic arc consisting of calcalcalic-granodioritic intrusion bodies and similar intermediate volcanites are exposed. They are called the Kohistan-Dras- and the Ladakh-GangdesePlutons. Granitic material from the latter outcrops in and around the Stakma valley between Shey Palace and Tikse Gompa, and leucogranitic dikes in it shows an intensly "grusic" weathering (Fig. 3, background). Strong weathering is the main reason for the rich supply of sediment to this valley, which has a length of around $15 \mathrm{~km}$ and an area of about $30 \mathrm{~km}^{2}$ (Fig. 2). The deposited material in the form of a giant fan of alluvial debris covers the northern side of the Indus valley between Shey and Tikse. It is evident that despite the dry climate of Ladakh, the Stakma River must have had a rich volume of water during rainy season or in times of extraordinary precipitation events not only in the past but also recently. A fresh cone of mud- and debris-flow represents the last depositional events on the western end on top of this fan (Fig. 2 and 3).

\section{Use of chörtens at Shey Palace for protection from debris-} flows

Exactly along the wide end of a mud-flow lying at the foot of the rocky hill at the northern front of the farm land of Shey village, hundreds of chörten have been erected. These are the oldest sacred cultural Buddhistic-Lamaistic structures in the area dating back to 1000 years (Fig. 2 and 3). These structures are erected at a geomorphologically very critical place. The village lies along the main flow direction of the debris- flow in front of the giant alluvial fan. The recent deposit of a young and fresh debris flow shows that it was stopped by the chörten before it reached to the village (Fig. 3 ). The position of these chörtens gives evidence that they were constructed for the protection of the village from the debris flows. Numerous chörtens of different size with special positioning must have additionally been used for almost 


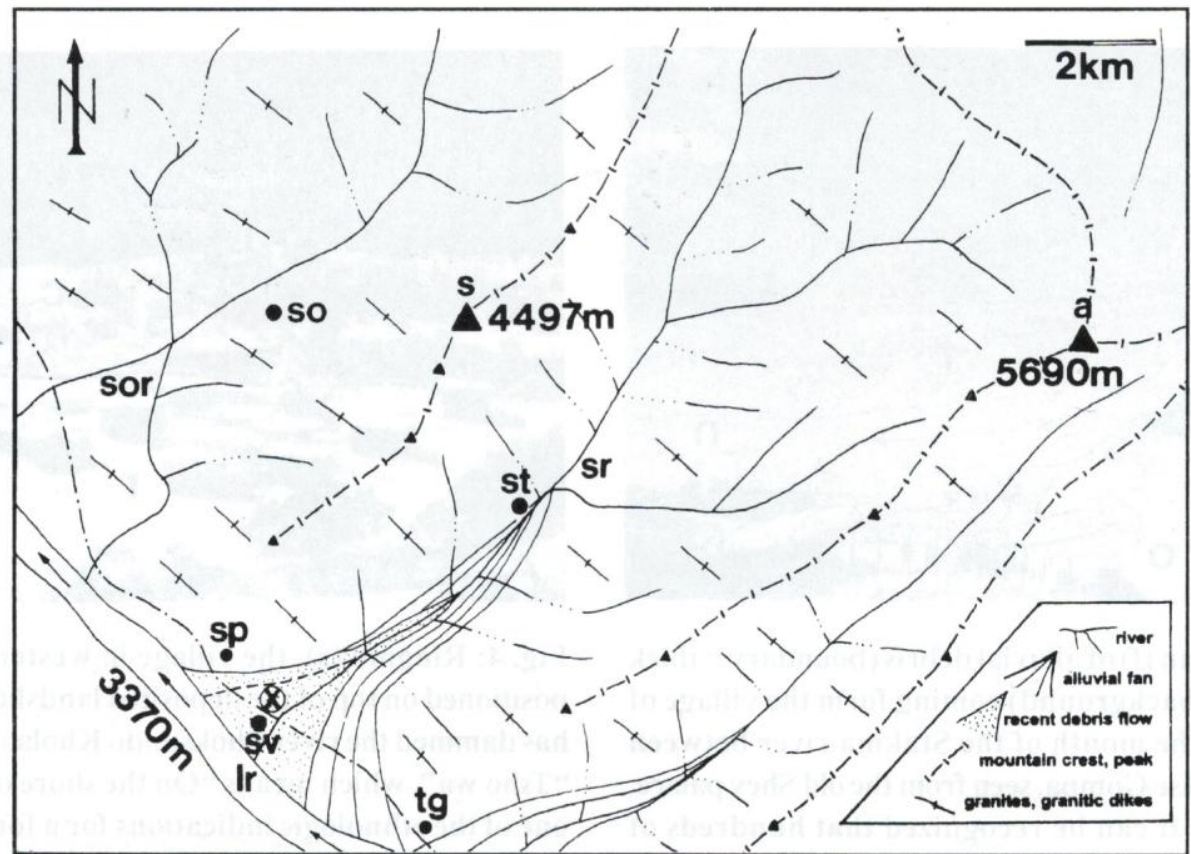

Fig. 2: Geomorpholgic sketch-map of the confluence of the Indus River (ir) with its northern tributary, the Stakma river (sr). The giant alluvial fan between Shey palace (sp) and Tikse Gompa (tg) shows a young, partly fresh mud-and debris-flow on its western edge, which must have endangered the village and the farm land of Shey village (sv) on the foot of the samenamed Gompa; the position of the chörten (x) rigth in the middle of this debris flow gives an idea of the "catastrophe-preventioneffect" of them; a-Arzu mountain, s-Sobu mountain, so-Sobu village, sor-Sobu river, st-Stakma village (base map: India and Pakistan, 1 : 250,000, Jammu and Kashmir, NI 43-8).

1000 years for reducing the velocity and dividing the temporary high flood of the stream. With this simple construction as a torrent reducing and controlling measure, an evenly distribution and sedimentation of the transported material has been guaranteed as well.

\section{DOLPA VALLEY, WESTERN NEPAL}

\section{Chörten as silent witnesses of hazardous events}

To constantly remind the future generations about the large and disasterous mountain hazard events of the past and their locations, and with a religious belief that chörten will help to prevent people from disasters (symbolic countermeasure) might have been the reasons that chörten were erected at various positions in the Himalayan mountains, which obviously show geomorphologic damages. In that case, their presence can be used as indicators for catastrophic events in the past and their time of erection, which can be more or less dated by the documentated history of the Buddhism, gives sometimes correct idea of the ages of those natural events themselves. One of these extraordinary locations of chörten is in the western part of Nepal, in Dolpa (also known as Dolpo).

The upper course of the river Suli Gad (= Phoksundo Khola, = Bauli Gad) lies about $25-30$ km north of the district's headquarters Dunai in western Nepal (Fig. 1). Lying within the Dhaulagiri Limestones of the southwestern Dolpa Synclinorium of the Tibetan-Tethys Sediments (Fuchs and Frank 1970), the river was dammed by a giant 40,000 years old landslide (Yagi 1997). An estimated volume of 1.5 billion cubicmetres of dislocated material on the bottom of the valley led to the creation of the $5 \mathrm{~km}$ long, $800 \mathrm{~m}$ wide and $200 \mathrm{~m}$ deep Phoksundo Lake, which has remined stable until now (Weidinger and Ibetsberger 2001). On the top of the landslide deposit a small village named Ringmo is located (Fig. 4). A monastery exists on the eastern side of the holy lake.

Although the present village Ringmo lies hundreds of metres away from the water front of the lake, it is still called Tsho-wa in Tibetan language, which means "on the shore of the lake". This is an indication for a village, which indeed was positioned close to the lake. If this village was situated at the same position as today, the water level in the lake must have been more than $10 \mathrm{~m}$ higher than today and an outburst of the lake might have been the reason for lowering the water level to the present position. Geological and geomorphological field data show that such a catastrophic outflow of the lake's waters in the past must have had occured (Fig. 4 and 5). From local mythological evidence, the event occurred about 1200 years ago. Depending on the former water level, this flood must have had a volume of 20-40 million cubic metres of water. It is an interesting fact that an oversized chörten exists close to the outlet of the lake which was constructed in the past by the local people. 


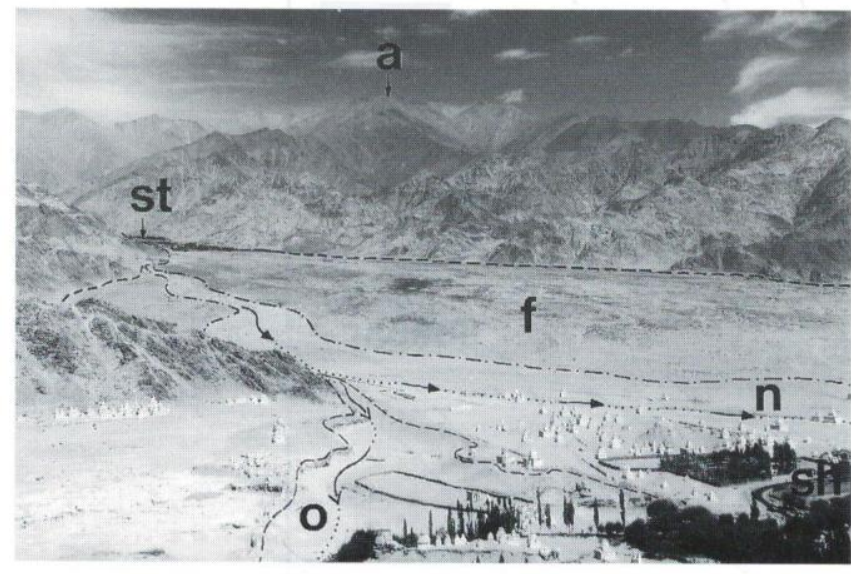

Fig. 3: The hudge fan ( $f$ ) of alluvial debris (boundary $=$ thick dashed line in the background) coming form the village of Stakma (st) near the mouth of the Stakma river between Shey palace and Tikse Gompa, seen from the old Shey palace, view towards NE. It can be recognized that hundreds of chörten have been erected to protect Shey village (sh) from flowing waters and depositioned debris. The special sheme of these erected chörten is not only of religious sence but also to devide flowing waters for reducing their velocity forcing the river to sediment the freight immedeatly just before to reach the village; another effect of the chörten was the changing of the old bed of the river (o), which had its way right towards the village (boundary $=$ thin dashed line) towards $E$, were the new bed ( $n$ ) is passing by the village; $\mathrm{a}=$ Arzu mountain.

\section{LANGTANG VALLEY, CENTRAL NEPAL}

The Langtang valley is situated about $60 \mathrm{~km}$ north of Kathmandu (Fig. 1) and lies in the crystalline rocks of the Higher Himalayan Sequence (Inger and Harris 1992; Macfarlane 1993). In this valley permanent settlements are found even at an altitude of almost $4,000 \mathrm{~m}$. With its high relief (Hejl et al. 1997) and morphologic overprinting by last ice-age glaciation, mountain hazards such as landslides, avalanches and debris flows are most common. Besides the occurrence of the world's biggest landslide in crystalline rocks at Tsergo $\mathrm{Ri}(4,984 \mathrm{~m})$ in the upper part of the valley (Weidinger et al. 1996), several smaller but recently active rock avalanches are reported from this area (Weidinger 1997 and 1998). Since the beginning of settlement in this remote and rugged terrain, the local people have had to live with this hazardous situation for hundreds of years. They were forced to develop simple methods to overcome this problem. While chörten do just mark the areas of falling stones and boulders from zones with faults and rock-fractures, maniwalls do act as active counter-measures against torrents in this area.

\section{Hazards on the south-flank of Langtang Lirung}

The nearly vertical south-flank of Langtang Lirung (7,234 $\mathrm{m}$ ) with its frequent avalanches composed of a mixture of ice

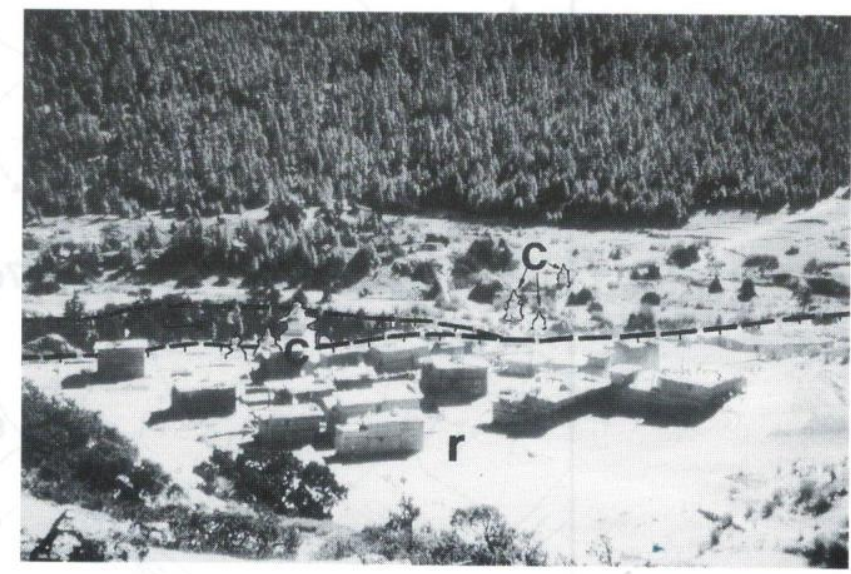

Fig. 4: Ringmo (r), the village in western Nepal, which is positioned on top of the deposited landslide-material, which has dammed the river Phoksundo Khola. Its tibetain name is "Tsho wa", which means "On the shore of the lake". This is one of the ethnologic indications for a former higher water level of the lake. The gully (boundary=thick dashed line, arrow shows direction of flowing) dreated by an eventually catastrophic outbreak of the lake is flanked by hudge chörten (c), (Photo: H. J. Ibetsberger 1995).

and moraine-material has been endangering the most populated area in the centre of this narrow valley between the villages of Langtang, Möldrong, and Shingdum (Fig. 6 and 7). Two giant cones of debris on the foot of this flank originating from different sized galciers in the rocky ice-wall are silent witnesses of hazardous processes that has gradually reduced the size of the little farmland on the bottom of the valley. The cultivated glacial terrace has been reduced to a slightly south-diping narrow stripe. This land is also endangered by the lateral erosion of the main river Langtang Khola. Both debris fans have reached to a height of about $50 \mathrm{~m}$ resting on the postglacial terrace. The terrace was created due to a temporary damming of the main valley just west of the Langtang village by a glacier, which flow from the northern glacial cirque on the footwall of Mera Peak $(6, .958 \mathrm{~m})$ (Heuberger and Ibetsberger 1998).

The western debris cone is fed by the river Yumthang $\mathrm{Chu}$, and the eastern one with an unnamed river. The first river has a high discharge of water with less sediment load, whereas the second one carries large sediment load originating from loosened moraines of its catchment. That is why a deep gully (10-15 m), has been formed in the western fan by the river, dividing the narrow farmland in two parts. The activity in the eastern fan is dominated by debris-flows. Due to debris deposits, Möldrong Village has recently lost $20,000 \mathrm{~m}^{2}$ of agriculture land, which constitutes a significant area in such a mountainous terrain. Both fans are active at present in the spring (melting waters) and monsoon period. Owing to the thin toe and the vegitation cover, rest of the area lies in a stable geomorphologic condition. The southern and easternmost part of the eastern fan was used as agricultural land in the recent past. 


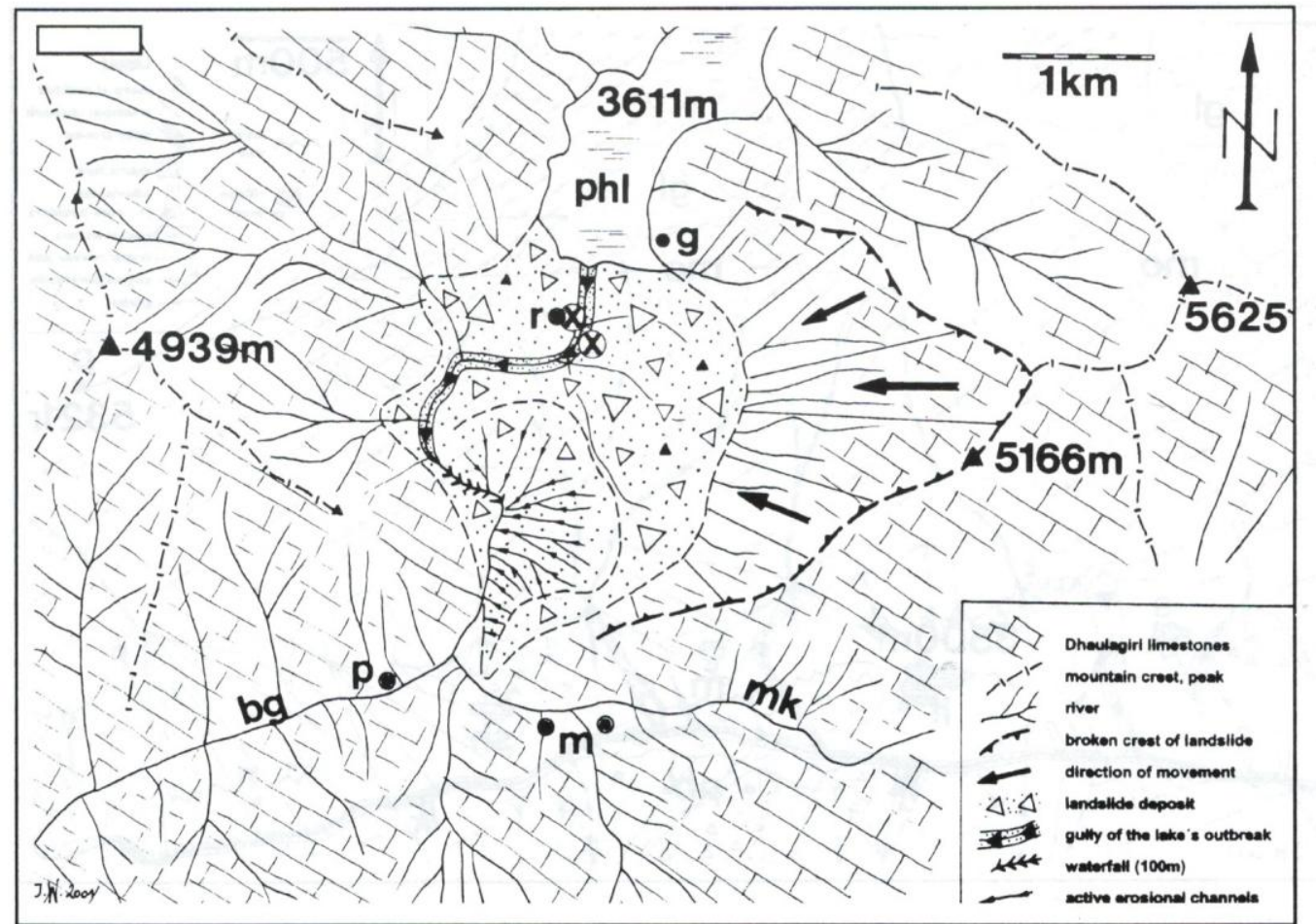

Fig. 5: Geologic-geomorphologic sketch-map of the landslide-area at Ringmo in western Nepal with the gully-formed outlet of the lake called Phoksudo Tal, which might have been caused by a catastrophic outburst; r-Ringmo village, g-Gompa (monastery), phi-Phoksundo lake, (X) position of the chörten flanking the outlet of the lake, bg-Bauli Gad or Phoksundo Khola (=river), p-Polam (police checkpost), m-Manduwa villages, mk-Manduwa Khola (= river), (base map: compiled from Fuchs and Frank 1970 and own observations).

\section{Mani-walls as protective measures against debris flow}

The east-west orientated trail leads around the debris cones in nearly two half-circled ways; this path is flanked by endless mani-walls on the side towards the northern cones and the high mountains (Fig. 6, 7 and 8). In some parts, the trail is even flanked by holly walls on both sides. The trail itself is used as water-channel during heavy rainfalls. The height of the walls varies from 1.2 to $2 \mathrm{~m}$. The width is about 1 to $2 \mathrm{~m}$ depending on the standpoint around the alluvial fans and requirements for torrent hazards. On several spots the wall has outlets, from where huge volume of water and even sediments coming from the cones can find their way without damaging the wall itself (Fig. 8). Most parts of the wall are 200-300 years old. Perhaps this may be the period when the first Tibetans settled in this remote area.

\section{Mani-walls as protective measures against bouncing} boulders

The activity of torrents and avalanches related to those hazardous fans has been the most important motivation for the local people in Langtang to erect the mani-walls, which can be seen just a few kilometres up along the valley of Nösapalli (Fig. 6). A geomorphologically stable cone of debris on the footwall of the peak Pangshungtramo $(5,321$ $\mathrm{m})$, which was related to the giant Tsergo Ri massmovement
(Weidinger and Schramm 1995) is partly flanked by maniwalls. This area is sometimes endangered by huge falling boulders from the top of the fan which reaches the bottom of the valley (Fig. 9). The height of the fan is over $450 \mathrm{~m}$.

On reaching the very active morainic landscape in front of the glacier Ledrup-Lirung Tsang, further upward along the valley with many streams and strong erosional processes, the distribution of the mani-walls again becomes denser.

\section{TISTA RIVER VALLEY, SIKKIM, INDIA}

Mani-walls as protectors from natural and/or anthropogenic hazards

In the early days, in remote Buddhist villages of the Himalaya, construction of mani-walls were most common in order to use it as stabilizers of the road or to stop erosion of steep slopes. In western Indian Himalaya, especially in Ladakh and Zanskar as well as in Sikkim in the east this tradition was most commonly practiced. Near the highway from Srinagar to Leh, mani-walls do act as erosion stabilizers at Lamayuru Gompa in Ladakh. But one of the main areas of this religious input to reduce geomorphologic hazards is in Sikkim along the main river Tista, where geological and climatic conditions contribute for extensive damages due to landslides. 


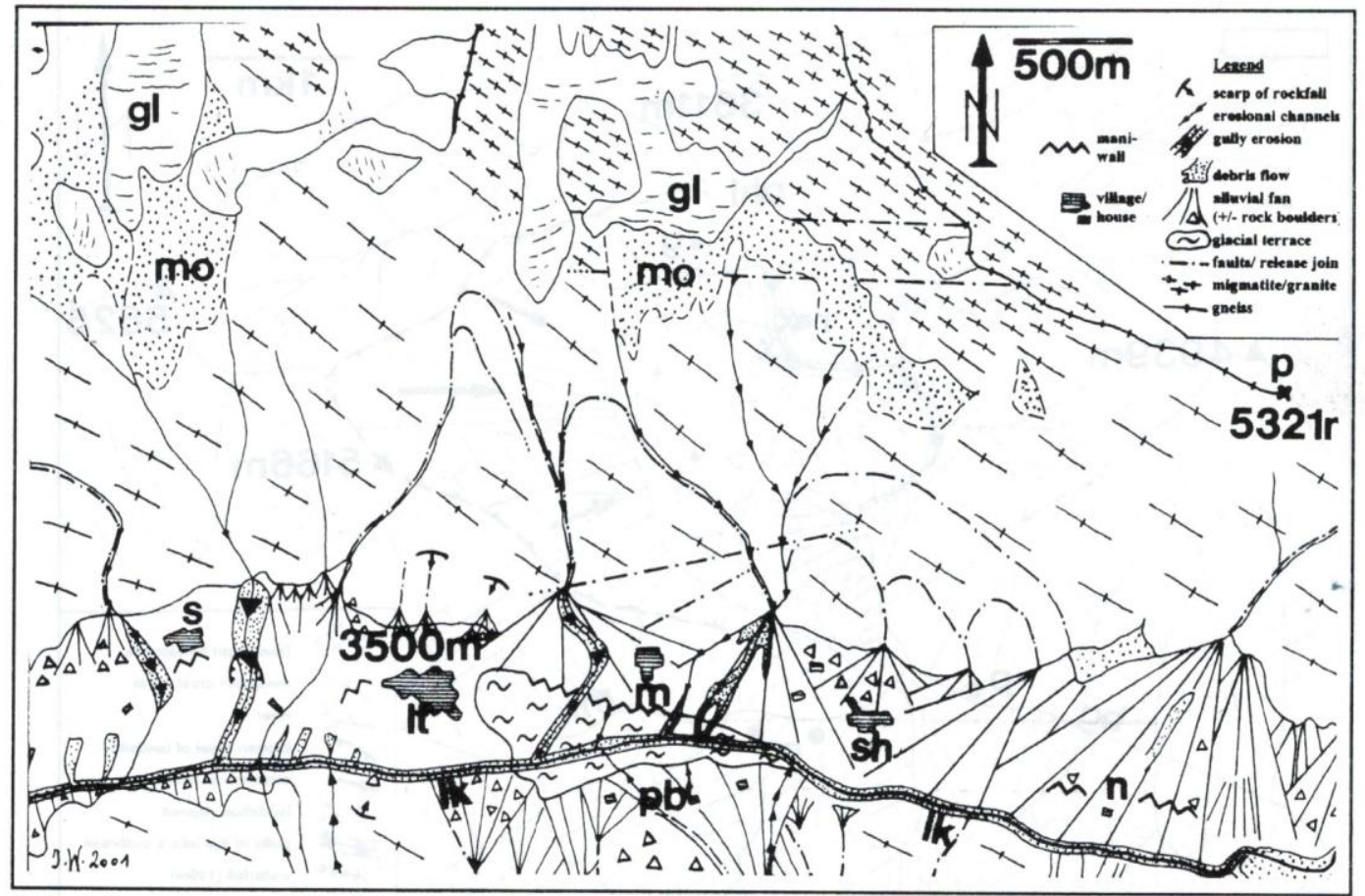

Fig. 6: Geologic-geomorphologic map of the central Langthang valley featuring the south-flank of Langthang Lirung (7,234 $\mathrm{m})$, its SE-crest to Pangshungtramo $(\mathrm{p}, 5,321 \mathrm{~m})$ and the position and distribution of the erected mani-walls on the bottom of the valley: s-Sangdansa Gompa (= monastery), It-Langtang village (3,500 m), m-Möldrong village, sh-Shingdum village, n-Nösapalli alp, pb-Palbag alp, lk-Langtang Khola (= river), gl-glacier, mo-moraine material.

The lower and middle course of the Tista River passes through the Lower Himalaya, where the rocks of so-called Daling Group are exposed. It is composed of thick, uniform and nearly monotonous pelitic and quarzitic shists. Near the MCT, the grade of metamorphism of the rocks gradually increases from south to north, and the shists pass into the gneisses and granites of the Higher Himalaya. In the lower part of the Tista valley, a large number of landslides have been reported. Most of them are related to constructions of roads and are, therefore, anthropogenic in nature. But additionally an interaction of several causes such as climate (e.g. excessive precipitation), geology, rugged topography, high seismic activity and other environmental factors are the main reasons for the destabilisation of mountain slopes and the occurance of landslides (Chandra 1975; Chatterjee and Chaudhuri 1989; Choubey and Rawat 1990; Larsen et al. 1999); Natarajan et al. 1980a; Natarajan et al. 1980b; Raghuraman 1975; Rudra et al. 1984; Sinha et al. 1975).

\section{Religious-mythologic markers along the Tista River}

An interesting fact is that the gomorphological hazards, which do not have any influence on human beings and structures, are of almost no interest for the local people. They are recognized and identified but not specially marked by religious monuments. These can be seen along the highway from Siliguri to Gangtok, where a large number of landslides on the left side of the river are not marked by any religious structures as this side of the highway is not endangered by the landslides. On the other hand, the right side of the river where the highway is endangered is partly flanked by mani-walls and chörtens. Many new roads are being constructed presently in the area and most of them have been consolidated by building new mani-walls or enlarging old ones. The system seems to have worked quite well. This can be also be seen around the endangered monasteries, such as Tashiding Gompa, east of Pemayangtse.

\section{CONCLUSIONS}

People following the Buddhistic faith started inhabiting the northern parts of the Himalayas long before. Their priests, normally called Lamas, devised various ways to prevent people and farmland from mountain hazards and processes degrading the environment in general such as soil erosion and landslides. Their techniques were quite practical. Their method of passing on the knowledge to the coming generations on the warning signs and counter-measures is unique. The erection of different sacred religious structures such as chörten and mani-walls was not only motivated by religious thinkings and faith but also from practical purpose. The chörten and mani-walls have often been used for controlling torrent-activity and erosion problems in general. In addition, the religious custom having been practiced by the locals to put stones on the walls while passing by these 


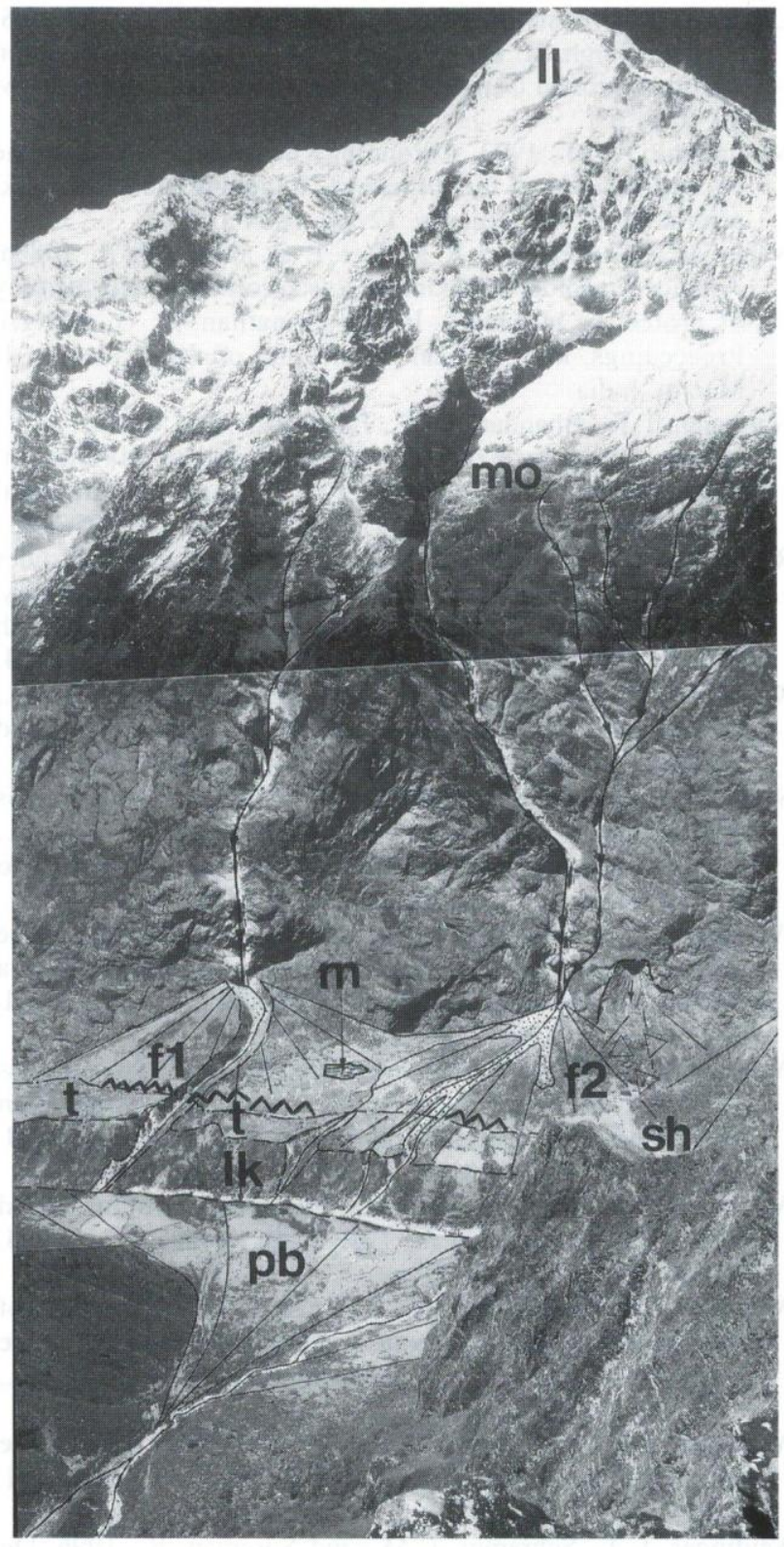

Fig. 7: Panoramic view from the southern side of the Langtang valley (altitude of standpoint: $4,550 \mathrm{~m}$ ) to the north, showing the village Möldrong $(\mathrm{m})$ at an altitude of $3,600 \mathrm{~m}$. Langthang Lirung (II) in the background is overthroning this scenery upto an elevation of 7,234 m, exactly 3,634 m above one of the highest permanent settlements in this region. Positioned between two hudge debris fans ( $\mathrm{f} 1$ and $\mathrm{f} 2$ ) created by avalanching along active erosional channels (à) from this steep wall, Möldrong has remained for hundreds of years without any damages by natural hazards. The farm land in front of the village positioned on a glacial terrace $(t)$ along the river Langtang Khola (lk) has been protected from debris flows by walls (zig-zag-line) which are build of stones with the carved buddhistic mantra "Om mani padme hum“ on them; $s$ =Shingdum village, $p b=$ Palbag alp.

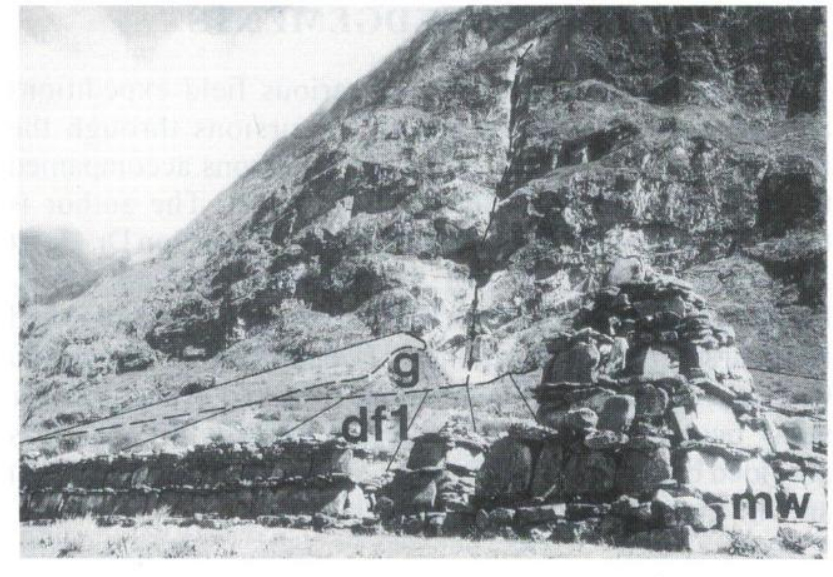

Fig. 8: View of the mani-walls with an outlet and a Chörten nearby ( $\mathrm{mw})$, which all are building a close half-circe around the western, hudge cone of debris (df 1 ) at Möldrong. Gully (g) in the background coming from an active erosional channel of the steep Langthang Lirung-southflank (à). The wall is preventing the tiny acres and the farm land from mudflow and gully-erosion.

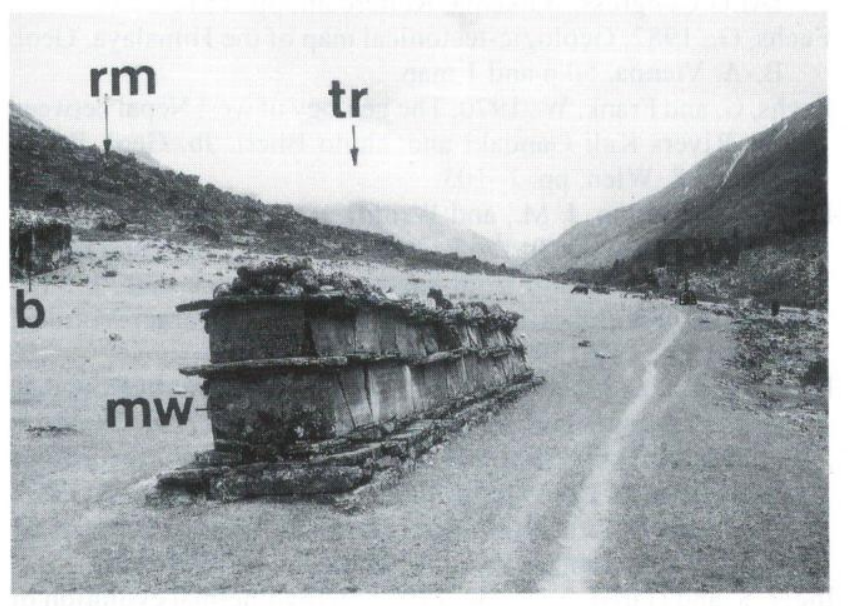

Fig. 9: Isolated mani-walls ( $\mathrm{mw}$ ) functioning as barrieres against rolling and bouncing boulders $(b)$ of rockfall material $(\mathrm{rm})$ originating from Pangshungtramo $(5,321 \mathrm{~m})$ and endangering the Alp meadows and the path near Nösapalli in the Langtang valley; view towards $\mathrm{E}, \mathrm{tr}=$ giant landslidedeposit of Tsergo $\mathrm{Ri}(4,984 \mathrm{~m})$ in the background.

structures has guaranteed the permanent fixing and repairs of the walls until recent times. The position of sacred structures in general in many cases is a good indicator for past catastrophic or hazardous natural events. They act as silent witnesses for such kind of mountain hazards. Therefore, during hazard mapping, a geoscientist may take note of such structures as they may hold clues for possible hazards which may not be obvious at the first instance. 


\section{ACKNOWLEDGEMENTS}

This study is a synthesis of various field expeditions and projects as well as private excursions through the Himalaya from 1990 to 2000. Many persons accompanied the author in the field during this period. The author is thankful to all of them. Particularly, I like to mention Dr. Horst J. Ibetsberger; Prof. Dr. J.M. Schramm and Prof. em. Dr. H. Heuberger (all of them from the University of Salzburg) and late Dhruba Prasad Madhikarmi (Department of Mines and Geology, Kathmandu) with whom I worked in the field for many occasions. Financial Support to those projects was provided by the Austrian Science Foundation Vienna (FWF) and the University of Salzburg.

\section{REFERENCES}

Chatterjee, B. and Chaudhuri, N. N., 1989, Landslide hazard zonation in Sikkim Himalaya. Rec. Geol. Surv. India, 122/3, JRNL Code: RGSINI, Calcutta, P76.

Chandra, B. H., 1975, Landslides in Teesta Valley. In: Chowdhury, M.K.R., Landslides and the erosion problems with special reference to Himalayan region, Calcutta, pp. 147-164.

Choubey, V. D. and Rawat, R. K., 1990, Engineering geological appraisal of the major landslides and their stabilization in the north Sikkim region (India). Proceedings of the $6^{\text {th }}$ International IAEG Congress, Balkema, Rotterdam, pp. 1547-2554.

Fuchs, G., 1982, Geologic-tectonical map of the Himalaya. Geol. B.-A. Vienna, $50 \mathrm{p}$ and 1 map.

Fuchs, G. and Frank, W., 1970, The geology of west Nepal between the Rivers Kali Gandaki and Thulo Bheri. Jb. Geol. B. A., Sdbd. 18, Wien, pp. 1-103

Hejl, E., Schramm, J. M., and Weidinger, J. T., 1997, Long term exhumation at the Tsergo Ri landslide area (Langthang Himal, Nepal): information from apatite fission track data. In: $12^{\text {th }}$ Himalaya-Karakorum-Tibet Workshop, Abstract Volume, Rome, pp. 149-150.

Heuberger, H. and Ibetsberger, H. J., 1998, Problems of Holocene glacier advances in Langtang, central Nepal. In: S. R. Chalise et al. (eds.), Ecohydrology of high mountain areas. Proceedings of the Internat. Converence on Ec. of H.M.A., Kathmadu 1996, Mountain Natural Resources' Division, Internat. Centre for Integrated Mountain Dev., Kathmandu, pp. 459-465.

Inger, S. and Harris, N. B. W., 1992, Tectonothermal evolution of the High Himalayan Crystalline Sequence, Langtang Valley, northern Nepal. J. Metamorph. Geol., v. 10, pp. 439-452.

Ives, D. J. and Messerli, B., 1989, The Himalayan Dilemma reconciling development and conservation. The United Nations University, Routledge, London and New York, 295 p.
Larsen, J. O., Grimstad, E., Bhasin, R., Dhawan, A. K., Verma, S. K., and Singh, R. B., 1999, Slideproblems and mitigation measures around Gangtok in Sikkim. J. Nepal Geol. Soc., v. 20 , p. 245 .

Macfarlane, A. M., 1993, Chronology of tectonic events in the crystalline core of the Himalaya, Langtang National Park, central Nepal. Tectonics, v. 12, pp. 1004-1025.

Natarajan, T. K., Bhandari, R. K., Rao, E. S., and Singh, A., 1980a, A major landslide in Sikkim; analysis, correction and efficacy of protective measures. In: Swaminathan, C. G. (Hrsg.), Proceedings, international symposium on landslides; v. 1, Meerut, India.

Natarajan, T. K., Bhandari, R. K., Tolia, D. S., and Murthy, A. V., $1980 \mathrm{~b}$, Some case records of landslides in Sikkim. In: Swaminathan, C. G. (Hrsg.), Proceedings, international symposium on landslides; v. 1, Meerut, India, pp. 455-460.

Raghuraman, S., 1975, Hydrology and its contribution to landslides with special reference to problems in Sikkim. In: Chowdhury, M. K. R. (Hrsg.), Landslides and toe erosion problems with special reference to Himalayan region, Calcutta, pp. 120-133.

Rudra, K., Bandyo Padhyay, G., and Bandyo Padhyay, M. K., 1984, Landslides in southern Sikkim. In: Verma, V. K. and Saklani, P. S., Himalaya; landforms and processes, Calcutta.

Sinha, B. N., Pradhan, S. R., and Sinha, P., 1975, Geological analysis of Padamchen slide, Sikkim.- In: Chowdhury, M. K. R., Landslides and toe erosion problems with special reference to Himalayan region, Calcutta, pp. 227-234.

Weidinger, J. T., 1997, The Lama Lodge - rockavalanche in the lower Langtang valley, Nepal: progressive development of a landslide in the High Himalayan Crystalline. J. Nepal Geol. Soc., v. 16, pp. 102-104

Weidinger, J. T., 1998, Progressive Development and Risk-Analysis of Rockavalanches; Case Study in the High Himalayan Crystalline of the Langthang National Park, central Nepal. J. Nepal Geol. Soc., v. 18, pp. $319-328$.

Weidinger, J. T., 2001, Torrent and avalanche Control by Sacred Buddhistic Buildings in the Langthang Himalaya, Nepal. J. Nepal Geol. Soc., v. 24, 49 p.

Weidinger, J. T. and Ibetsberger, H. J., 2001, Landslide dams of Tal, Latamrang, Ghatta Khola, Ringmo and Dharbang in the Nepal Himalayas and related hazards. J. Nepal Geol. Soc., v. 22 , pp. $371-380$

Weidinger, J. T. and Schramm, J. M., 1995, A Short Note on the Tsergo Ri Landslide, Langtang Himal, Nepal. J. Nepal Geol. Soc., v. 11, pp. 281-287

Weidinger, J. T., Schramm, J. M., and Surenian, R., 1996, On preparatory causal factors, initiating the prehistoric Tsergo $\mathrm{Ri}$ landslide (Langthang Himal, Nepal). Tectonophysics, v. 260. pp. 95-107.

Yagi, H., 1997, Origin of the Phoksundo Tal (lake), Dolpa district, western Nepal. J. Nepal Geol. Soc., v. 15, pp. 1-7. 